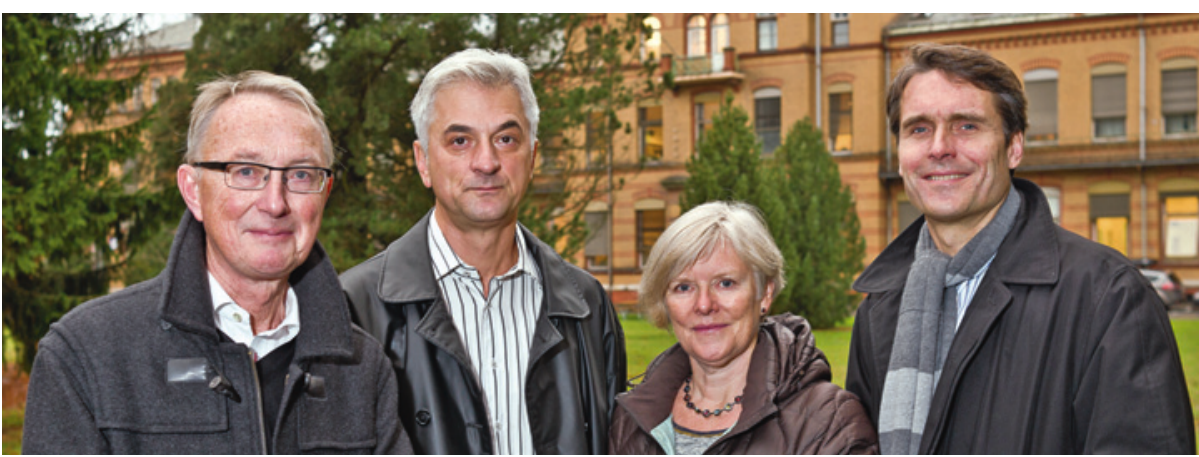

Fra venstre: Knut Engedal, Srdjan Djurovic, Ingun Ulstein og Ole A. Andreassen. Foto Øystein H. Horgmo, Universitetet i Oslo

\title{
Genvariant øker risikoen for demens og kognitiv svikt
}

Norske forskere har bidratt til oppdagelse av en ny genvariant som gir økt risiko for Alzheimers sykdom og kognitiv svikt.

Alzheimers sykdom er den vanligste formen for demens hos eldre. Genvarianter som polymorfisme av apolipoprotein E (ApoE) har vist seg å øke risikoen for den vanligste formen for Alzheimers sykdom. Det har imidlertid vært vanskelig å finne flere genetiske varianter som leder til sykdommen, og nesten ingen sjeldne genvarianter er funnet.

Nå har forskere brukt en helt ny genetisk metode, basert på dypsekvensering av genomet, hos 2261 personer fra Island. Man la vekt på genendringer som sannsynligvis ville påvirke proteinfunksjoner (1). Disse variantene ble imputert for et stort antall personer med og uten Alzheimers sykdom og deretter testet for replikasjon ved hjelp av pasient-kontroll-populasjoner fra USA, Norge, Nederland og Tyskland. I tillegg ble det gjort studier av sammenhengen med kognitiv funksjon generelt.

En sjelden missense-mutasjon (rs75932628-T) i genet som koder for utløsende reseptor uttrykt på myeloide celler 2 (TREM2), spådd å resultere i en R47H-substitusjon, ble funnet å gi risiko for Alzheimers sykdom på Island (OR 2,92; $\left.\mathrm{p}=3,42 \cdot 10^{-10}\right)$. Assosiasjon ble bekreftet i replikasjonspopulasjoner, med en høy effektstørrelse og signifikansverdi i det kombinerte materialet (OR $\left.2,90, \mathrm{p}=2,1 \cdot 10^{-12}\right)$. Bærere av rs75932628T-mutasjonen som var i alderen 80-100 år og som ikke hadde Alzheimers sykdom, hadde dårligere kognitiv funksjon enn ikkebærere $(\mathrm{p}=0,0029)$.

- Disse funnene tyder på at denne varianten av TREM2-genet inngår i patogenesen ved Alzheimers sykdom, sier professor Ole A. Andreassen ved Universitetet i Oslo. - Ettersom man antar at TREM2 spiller en antiinflammatorisk rolle i hjernen, kan denne mutasjonen føre til økt predisposisjon for Alzheimers sykdom gjennom en primær forstyrrelse av inflammasjonsprosesser. Dette er et nytt konsept for patofysiologien ved Alzheimers sykdom, siden man hittil har antatt at inflammatorisk aktivering har vært sekundært til danningen av amyloide plakk i hjernen, sier Andreassen.

\section{Forskergruppen}

Prosjektet har fra norsk side vært ledet av Ole A. Andreassen, med bidrag innen molekylærgenetiske analyser fra Srdjan Djurovic og med kliniske data fra Knut Engedal og Ingun Ulstein, alle medforfattere av artikkelen. Forskningen er basert på et samarbeid med deCODE Genetics på Island, som også nylig ledet til oppdagelse av en genvariant i APP som beskytter mot demens og kognitiv svikt (2). Disse prosjektene er del av en satsing for å forstå mekanismer for kognitiv svikt ved $\mathrm{KG}$ Jebsen Senter for Psykoseforskning ved Oslo universitetssykehus, Universitetet i Oslo og Universitetet i Bergen (Andreassen, Djurovic). Teamet ved Nasjonalt kompetansesenter for aldring og helse (Engedal og Ulstein) leder et større nettverk innen klinisk forskning på aldring og demens.

\section{Erlend Hem}

erlend.hem@medisin.uio.no

Tidsskriftet

\section{Litteratur}

1. Jonsson T, Stefansson H, Steinberg S et al. Variant of TREM2 associated with the risk of Alzheimer's disease. N Engl J Med 2012. E-publisert 14.11.2012.

2. Jonsson T, Atwal JK, Steinberg $S$ et al. A mutation in APP protects against Alzheimer's disease and age-related cognitive decline. Nature 2012; 488: $96-9$

\section{Publisert først på nett 15.11. 2012.}

\section{Ordforklaringer}

Missense-mutasjon: Forandret DNA-sekvens som medfører en endret aminosyre i proteinet. Effekten avhenger av type endring og hvor i proteinet den forekommer.

Dypsekvensering: En DNA-sekvenseringsteknikk hvor et stort antall DNA-fragmenter leses samtidig, slik at hele DNA-koden blir kartlagt (ca. tre milliarder basepar).

Imputering: En statistisk metode for beregning av manglede data i store datamasser, her brukt for å beregne en spesifikk genetisk variant basert på kjente genvarianter (bestemt ved genotypingl i naboregionene.

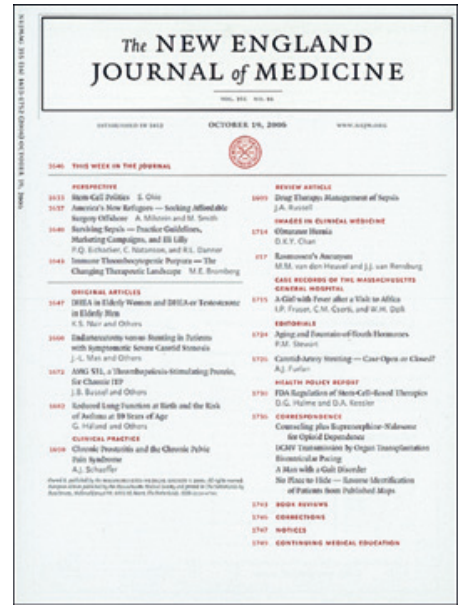

Artikkelen ble e-publisert 14.11. 2012 i New England Journal of Medicine (www.nejm.org), som er verdens høyest rangerte generelle medisinske tidsskrift. (c) New England Journal of Medicine 